\title{
Management of Prostatomegaly (Izam-I-Ghudda-I-Mazi) in Unani System of Medicine: An Overview
}

\author{
Quraishi HA$^{1 *}$, Arsheed Iqbal ${ }^{2}$, Shabir Ahmad Bhat ${ }^{3}$, Naquibul \\ Islam $^{4}$ and Qamar Alam Khan ${ }^{5}$ \\ ${ }^{1}$ M.D. Scholar Unani Medicine, University of Kashmir, India \\ ${ }^{2}$ Research officer Unani (Scientist-III), University of Kashmir, India \\ ${ }^{3}$ M.D. Scholar Unani Medicine, University of Kashmir, India \\ ${ }^{4}$ Professor and HOD Unani Medicine, University of Kashmir, India \\ ${ }^{5}$ Clinical Registrar, Jamia Hamdard, India
}

*Corresponding author: Haider Ali Quraishi, M.D. Scholar Unani Medicine, Regional Research Institute of Unani Medicine, University of Kashmir, Srinagar, Kashmir, India, Tel: +91 9540229109; Email: drhaiderjamiahamdard@gmail.com

\section{Abstract}

Prostatomegaly is the enlargement of prostate gland in elderly males which results urinary symptoms in them. The prevalence of prostatomegaly is age dependent with the initial development usually after 40 years reaching approximately 90 percent after 70 years of age. Since prostatomegaly itself is not a fatal disease but its most important outcome is urinary flow obstruction, which is miserable for the patient and affects physical activities and mental health of the person. The symptoms of prostatomegaly include hesitancy, increased frequency of micturition, dribbling, narrow stream, nocturia, retention of urine, urgency, incontinence etc. Great Unani physician have been managing depending upon the age and nature of the symptoms. The great ancient scholars have also managed this ailment by different regimental therapies, pharmacotherapy and dietotherapy.

Keywords: Prostatomegaly; Warm-e-Ghudda-e-Mazi; Micturition; Unani Medicine

Abbreviations: BPH: Benign Prostatic Hyperplasia; TURP: Trans-Urethral Resection of Prostate; RRIUM: Regional Research Institute of Unani Medicine; PSA: Prostate-Specific Antigen; PZ: Peripheral Zone, TZ: Transitional Zone; CZ: Central Zone.

\section{Introduction}

In classical literature of Unani System of Medicine prostatomegaly has been mention as Izam-i-Ghudda-iMazi Sada, Sala 'a Ghudda-e-Mazi, Warm-e-Ghudda-e-Mazi, and Warm-e-Unq-e-Masanah [1-3]. It is a condition 
resembling the clinical feature discussed under Usr-i-Bawl (Dysuria), Ihtibas-i-Bawl (Retention of Urine) and Taqtiri-Bawl (Dribbling of Urine), narrow stream, urgency, incontinence etc. in classical literature of USM. Unani Physicians have mentioned that Warm-i-Aza-i-Mujawira (Inflammation/swelling of neighboring organs) of urethra may compress it causing obstruction to flow urine [4,5]. These conditions may be correlated to Benign Prostatic Hyperplasia (BPH) where enlarged prostate compresses prostatic urethra and produces symptoms such as hesitancy, intermittent voiding, diminished stream, incomplete emptying, and post void leakage.

It is caused by the abnormal accumulation of Balgham Ghaliz or Mawad-e-Ghaliz (Thick phlegm) which has been mentioned as the leading cause of swelling (Auram) / inflammation of any Azw Ghudadi (Gland) of the body [6]. It is characterized by urinary frequency, hesitancy, strangury and urgency with weak urinary stream. Patient may have feeling of incomplete bladder emptying, straining and terminal dribbling. Acute and chronic urinary retention may also be present. Unani physicians are treating the symptoms of BPH for centuries with safe Unani herbal remedies.

\section{Review of Literature}

Cause of Prostatomegaly is not much exactly understood but it is now clear that androgens have central role in its development [7]. In Unani system of medicine Prostatomegaly has been described under the headings of Sala'a Ghudda-e-Mazi, Warm-e-Ghudda-eMazi, and Warm-e-Unq-e-Masanah. However mostly in our classical texts symptomatic treatment of Prostatomegaly can be found under different headings like Ehtabass-eBaul, Taqteerul Baul, Usr-e-Baul etc [8]. Father of medicine Hippocrates (Buqrat) described Auram (swellings) because of abnormality in four humors (Akhlate arba), a soft swelling is due to (Khilt-e-Balgham), a hard swelling (Warm-e-Salb) or Sala'a due to black humour Khilt-eSauda and third type is combination of the two (Balgham and Sauda). Attiba have categorized Sala'a (tumor) under the heading of Warm (an abnormal growth or swelling) [9]. Maseehi described Sala' $a$ as a swelling or over growth due to Balgham or Mawad-e-Galeez [10].

The paradigm for the management of Prostatomegaly has shifted from being purely surgical to a combination of medical and surgical management in past two decades. Though trans-urethral resection of prostate (TURP) remains the gold standard in Prostatomegaly management, new clinical research has opened up avenues of medical management. Medical management is effective in reducing the symptoms and prostate size, but allopathic medicine do have various side effects like erectile dysfunction, loss of libido, impotency, vertigo, cardiovascular disorders etc $[11,12]$. Unani physicians are treating the symptoms of Prostatomegaly by different Unani formulation and regimen.

\section{Incidence}

Benign prostatic hyperplasia (BPH) prevalence in Ghana is responsible for $60 \%$ acute retention of urine and $28.6 \%$ of haematuria. Worldwide prevalence of $\mathrm{BPH}$ varies from $20-62 \%$ in men over 50 years and this includes USA, UK, Japan and Ghana. BPH co-existing with PC - Reports from USA, UK and Japan and Ghana reveal moderate association of $\mathrm{BPH}$ and $\mathrm{PC}$ is $3-20 \%$.

Prostate Cancer prevalence - There is high prevalence in USA, Scandinavian Countries, African Americans (AA) and Caribbean blacks. Ghana, Trinidad \& Tobago have reported high prevalence of $6-10 \%$ in men aged 50 years and above. Overall PC causes $18 \%$ of disorders of the prostate gland. The worldwide incidence in men over 50 years is $11.7 \%$ that is 15 th commonest of new cancers worldwide, $19 \%$ of new cancers in developed countries and $5 \%$ in developing countries [13]. The prevalence per population is lowest in Asia/China 1.9\% or 10/100,000 in Caucasian Americans $1.4-2.4 \%$ or $104 / 100,000$, African Americans $2.2-5.1 \%$ or $272 / 100,000$, in Caribbean Men about $5-10 \%$ and we have established in Ghanaian Men from $6.3 \%-7 \%$ which is on the high side $[14,15]$.

Management of Prostatomegaly by different Unani formulation and regimental therapies.

- Ilaj-Bil-Ghiza (Dietotherapy)

- Ilaj-Bil-Dawa (Pharmacotherapy)

- Ilaj-Bil-Tadbeer (Regimenal therapy)

- Ilaj-Bil-Yad (Surgery)

Usul-i-Ilaj (Principles of Treatment)

- Tanqiya (Evacuation of Morbid matter i.e. Mawad-eGhaliz).

- Talyin-o-Irkha-o-Tahlil-i-Waram (To soften, relax and resolve the swelling / Auram).

- Ikhraj-i-Bawl Bazari-a-Qasatir (Urethral catheterization) in acute retention.

Ilaj-Bil-Dawa (Pharmacotherapy)

- Oral Administration of Maul-Usul with castor oil.

- Oral administration of Joshanda (decoction) of following drugs (Table 1) along with Gulqand in the morning [16]. 


\begin{tabular}{|c|c|c|}
\hline \multicolumn{2}{|c|}{ Drugs } & \multirow{2}{*}{ Miqdaar (Quantity) } \\
\hline Unani Names & Botanical Names & $10.5 \mathrm{gm}$ \\
\hline Badranjboya & Nepeta ruderalis Ham. & $10.5 \mathrm{gm}$ \\
\hline Badiyan & Foeniculum vulgare Gaertn. \\
\hline
\end{tabular}

Table 1: Ingredients of Joshanda.

- Oral administration of Joshanda (decoction) of Badiyan (Foeniculum vulgare Gaertn.) 10.5 gm. with Gulqand Asli 35gm in the morning [17].
- Oral administration of Safoof (Powder) of following ingredients (Table 2) along with Gulqand in the morning.

\begin{tabular}{|c|c|c|}
\hline \multicolumn{2}{|c|}{ Drugs } & \multirow{2}{*}{ Miqdaar (Quantity) } \\
\hline Unani Names & Botanical Names & $4.5-7.5 \mathrm{gm}$ \\
\hline Zanjabil & Zingiber officinale Roscoe. & $4.5-7.5 \mathrm{gm}$ \\
\hline Turbud & Ipomea turpethum Br. & $4.5-7.5 \mathrm{gm}$ \\
\hline Mastagi & Pistacia lentiscus Linn. & \\
\hline
\end{tabular}

Table 2: Ingredients of Safoof.

- Oral administration of 3.5gm of Habb-e-Khizran (Pills Khizran) (prepared with fallowing ingredients) (Table $3)$.

\begin{tabular}{|c|c|c|}
\hline & Drugs & \multirow{2}{*}{ Miqdaar (Quantity) } \\
\hline Unani Names & Scientific Names & $10.5 \mathrm{gm}$ \\
\hline Ayarij-i-Fayqra & Ayarij-i-Fayqra & $8.75 \mathrm{gm}$ \\
\hline Ghariqun & Agaricus alba Linn. & $5.25 \mathrm{gm}$ \\
\hline Shahm-i-Hanzal & Cirullus colocynthis Schard. & $24.5 \mathrm{gm}$ \\
\hline Turbud & Ipomea turpethum Br. & $4.5 \mathrm{gm}$ \\
\hline Jaoshir & Ferula galbaniflua Boiss. & $7 \mathrm{gm}$ \\
\hline Nawsharad & Sal ammoniac & $4.5 \mathrm{gm}$ \\
\hline Saqmuniya & Convolvulus scammonia Linn. & Mix with all above \\
\hline Juice of Gandana & Allium ampeloprasum Linn & \\
\hline
\end{tabular}

Table 3: Ingredients of Habb-e-Khizran.

- Oral administration of 7-10.5gm Habb-e-Wasili (Pills

Wasili) prepared with fallowing ingredients (Table 4).

\begin{tabular}{|c|c|c|}
\hline & Drugs & \multirow{2}{*}{ Miqdaar (Quantity) } \\
\hline Unani Names & Scientific Names & $03.5 \mathrm{gm}$ \\
\hline Sumbul al Tib & Nardostachys jatamansi & $03.50 \mathrm{gm}$ \\
\hline Salikha & Cinnamomum aromaticum Nees & $17.50 \mathrm{gm}$ \\
\hline Shahm-i-Hanzal & Cirullus colocynthis Schard. & $24.5 \mathrm{gm}$ \\
\hline Turbud & Ipomea turpethum Br. & $03.50 \mathrm{gm}$ \\
\hline Habb-i-Balsan & Fruit of Commiphora opobalsamum Linn. & $03.50 \mathrm{gm}$ \\
\hline Asarun & Asarun europaeum & $14.00 \mathrm{gm}$ \\
\hline Saqmuniya & Convolvulus scammonia Linn. & $03.50 \mathrm{gm}$ \\
\hline Ud-i-Balsan & Commiphora opobalsamum Linn. & $03.50 \mathrm{gm}$ \\
\hline Mastagi & Pistacia lentiscus Linn. & $03.50 \mathrm{gm}$ \\
\hline Darchini & Cinnamomum zeylanicum Linn. & $03.50 \mathrm{gm}$ \\
\hline Zafaran & Crocus sativus Linn. & $56.00 \mathrm{gm}$ \\
\hline Sibr & Aloe vera Linn. & \\
\hline
\end{tabular}




\begin{tabular}{|c|c|c|}
\hline Ustukhudus & Lavandula stoechas Linn & $17.50 \mathrm{gm}$ \\
\hline Namak Hindi & Common salt & $07.00 \mathrm{gm}$ \\
\hline
\end{tabular}

Table 4: Ingredients of Habb-e-Wasili.

- Oral administration of Safoof (Powder) of Ustukhudus (Lavandula stoechas Linn) in a dose of $1 \mathrm{gm}$ with $12 \mathrm{gm}$ Of Itrifal Saghir, followed by administration of Joshanda (decoction) of Gul-i-Khatmi (Flower of Althae officinalis Linn.) 3gm., Mawiz Munaqqa (Vitis vinefera Linn.) 10 pices, Tukhm-e-Kasni (seed of Cichorium intybus Linn.) $6 \mathrm{gm}$. Mixed with $12 \mathrm{ml}$ of honey and sprinkled with 6gm of Asphol (Plantago ovata Forsk).

- Abzan (Sitz bath) with Joshanda (decoction) of following drugs [18] (Table 5).

\begin{tabular}{|c|c|c|}
\hline \multicolumn{2}{|c|}{ Drugs } & \multirow{2}{*}{ Miqdaar (Quantity) } \\
\hline Unani Names & Botanical Names & $4.5-7.5 \mathrm{gm}$ \\
\hline Babuna & Matricaria chamomilla Linn. & $4.5-7.5 \mathrm{gm}$ \\
\hline Shibit & Anethum sowa Roxb. & $4.5-7.5 \mathrm{gm}$ \\
\hline
\end{tabular}

Table 5: Ingredients of Joshanda with Abzan.

- Abzan (Sitz bath) with Joshanda (decoction) of following drugs (Table 6).

\begin{tabular}{|c|c|c|}
\hline \multicolumn{2}{|c|}{ Drugs } & \multirow{2}{*}{ Miqdaar (Quantity) } \\
\hline Unani Names & Botanical Names & \\
\hline Babuna & Matricaria chamomilla Linn. & 4.5-7.5gm \\
\hline Nakhuna (Pods) & Trigonella uncata Boiss. & $4.5-7.5 \mathrm{gm}$ \\
\hline Banafsha & Viola odorata Linn. & $4.5-7.5 \mathrm{gm}$ \\
\hline Shih & Artemisia maritima Linn. & $4.5-7.5 \mathrm{gm}$ \\
\hline Qaysum & Achillea millefolium Linn. & $4.5-7.5 \mathrm{gm}$ \\
\hline Marzanjosh & Oliganum vulgare Linn. & $4.5-7.5 \mathrm{gm}$ \\
\hline
\end{tabular}

Table 6: Ingredients of Joshanda with Abzan.

- Abzan (Sitz bath) with Joshanda (decoction) of following drugs (Table 7) in quantity of $24 \mathrm{gm}$ each.

\begin{tabular}{|c|c|}
\hline \multicolumn{2}{|c|}{ Drugs } \\
\hline Unani Names & Botanical Names \\
\hline Babuna & Matricaria chamomilla Linn. \\
\hline Nakhuna ( Pods) & Trigonella uncata Boiss. \\
\hline Banafsha & Viola odorata Linn. \\
\hline Shibit & Anethum sowa Roxb. \\
\hline Barg-i-Turb & Raphanus sativus Linn. \\
\hline Bazr-i-Katan & Tribulus terristris Linn. \\
\hline Khar Khasak & Apium graveolens Linn. \\
\hline Karafs & Adiantum capillus-veneris Linn. \\
\hline Parsiyaoshan & Althaea officinalis Linn. \\
\hline Khatmi & Trigonella foenum-graeceum Linn. \\
\hline Hulba & Wheat husk \\
\hline Sabus (Wheat husk) & Cabbage \\
\hline Barg-i-Karnab (Cabbage) &
\end{tabular}

Table 7: Ingredients of Joshanda with Abzan. 
- Natul (Irrigation) with Joshanda (decoction) of following drugs (Table 8).

\begin{tabular}{|c|c|c|}
\hline \multicolumn{2}{|c|}{ Drugs } & \multirow{2}{*}{ Miqdaar (Quantity) } \\
\hline Unani Names & Botanical Names & $4.5-7.5 \mathrm{gm}$ \\
\hline Babuna & Matricaria chamomilla Linn. & $4.5-7.5 \mathrm{gm}$ \\
\hline Shibit & Anethum sowa Roxb. & $4.5-7.5 \mathrm{gm}$ \\
\hline Bekh-i-Khatmi (Root) & Pistacia lentiscus Linn. & . \\
\hline
\end{tabular}

Table 8: Ingredients of Joshanda with Natul.

- Application of paste of following drugs (Table 9) on the bladder area after mixing with juice of cabbage and Roghan-i-Khasak.

\begin{tabular}{|c|c|c|}
\hline \multicolumn{2}{|c|}{ Drugs } & \multirow{2}{*}{ Miqdaar (Quantity) } \\
\hline Unani Names & Botanical Names & $4.5-7.5 \mathrm{gm}$ \\
\hline Babuna & Matricaria chamomilla Linn. & $4.5-7.5 \mathrm{gm}$ \\
\hline Ard-i-Hulba (Flour of seed) & Trigonella foenum-graeceum Linn. & $4.5-7.5 \mathrm{gm}$ \\
\hline Khubazi & Malva sylvestris Linn. & $4.5-7.5 \mathrm{gm}$ \\
\hline Banafsha & Viola odorata Linn. & $4.5-7.5 \mathrm{gm}$ \\
\hline Nakhuna (Pods) & Trigonella uncata Boiss. & \\
\hline
\end{tabular}

Table 9: Ingredients of paste.

- Application of paste of Shora Qalmi (Potassium nitrate) on the bladder area.

- Application of Roghan-i-Khasak at pubic region.

- Application of Roghan-i-Babuna at pubic region.

- Application of Roghan-i-Gul at pubic region.

- Application of hot paste of Rewand Chini (Rheum emodi Wall.) mixed with Arq-i-Badyan at pubic area, testicles and around urethra.

\section{Compound Unani Drugs}

The compound formulations which have been given in Unani classical literature for the management of prostatomegaly are discussed below as in Table 10.

\begin{tabular}{|c|c|c|}
\hline S.No. & Compound Unani Drugs & Doses \\
\hline 1 & Itrifal Ghudadi [17] & 5gm twice a day. \\
\hline 2 & Habb-i-Ayarij [5] & 2 pills twice a day. \\
\hline 3 & Itrifal Saghir [17] & 5-10gm at bed time. \\
\hline 4 & Sharbat Dinar [16] & 10-20ml after every meal. \\
\hline 5 & Banadiq-ul-Bazur [5] & 2 pills thrice a day. \\
\hline 6 & Arq-i-Mako [16] & 125ml twice a day. \\
\hline 7 & Roghan-i-Khasak [18] & Local application on pubic region. \\
\hline 8 & Habb-i-Hindi [16] & 2 pills thrice a day. \\
\hline 9 & Roghan-i-Babuna [18] & Local application on pubic region. \\
\hline 10 & Roghan-i-Gul [18] & Local application on pubic region. \\
\hline
\end{tabular}

Table 10: Compound Formulation (Murakkab Adviya).

Ilaj-Bil-Tadbeer (Regimenal therapy)

- Natul (Irrigation)

- Urethral catheterization

- Abzan (Sitz bath)

Dietary Recommendations (Ilaj-Bil-Ghiza)
- Aghziya Murattiba

Dietary Restrictions

- Aghziya Hamiza

- Aghziya Ghaliza

- Aghziya Qabiza 
- Aghziya Muwallid-i-Sawda

- Aghziya Muwa;;id-i-Balgham

Investigation Required

- USG (W/A).

- Serum prostate-specific antigen (PSA).

- Uroflowmetry.

\section{Methodology}

The databanks used to get information from journals and articles are Google, PubMed, Science Direct, Scopus and Google Scholar. For the search of primordial and current Unani classical literature author visited Library of Regional Research Institute of Unani Medicine (RRIUM), Srinagar, J \& K, India and School of Unani Medical Education and Research Jamia Hamdard, New Delhi.

\section{Conclusion}

The morphological anatomy of the prostate gland has been established. They are the peripheral zone (PZ), transitional zone (TZ), central zone (CZ), the anterior fibro muscular area and the pre prostatic area. The contributions of zonal areas in a normal gland are PZ 70$80 \%$, TZ 10\%, CZ 20\%. In benign prostatic hyperplasia/hypertrophy/enlargement (BPH/BPE), only the transitional zone is affected and constitutes $100 \%$ of prostatomegaly. So it has been observed that these formulations when used clinically have marked effect in reducing the volume of the prostate by acting on the transitional zone. To overcome the misery of the prostatic symptoms and to maintain the proper sleep, the different regimenal therapies employed by Unani physician from time to time has in general gained the importance of Unani system of medicine for prostatomegaly.

\section{References}

1. Jeelani HG (1923) Makhzanul Jawahir (Tibbi Lugat), Manager Tibbi Kutbkhana, Lahore, 607: 917-918.

2. Alqamri AMH (2010) Ghina Muna $1^{\text {st }}$ (Edn), CCRUM, New Delhi, 497: 309-310.

3. Ibne Sena (2010) Alqanoonfittib (Urdu translation by Ghulam Hasnain kantoori), Ejaz publishing House, New Delhi, 3: 1023.

4. Ibn Sina (1411) Al-Qanun-fil-Tibb, (Part II), Jamia Hamdard, New Delhi, 3: 762-781.

5. Mohammad Azam Khan (1906) Iksir-i-Azam, Matab Nami, Munshi Naval Kishor Lucknow, 3: 498-516.
6. Nafis B, Iwaz (1326) Sharah-al-Asbab-wa-al-Alamat, Matab Nami, Munshi Naval Kishor Lucknow, 2: 193205.

7. Tho TD, Thanh NV, Thuc DV, Khanh Hy DT, Bien TK, et al. (2005) Assessment of therapeutic effect of softgel Crinum latifolium for benign prostate hypertrophy. Ministry of Health, Hanoi.

8. Qarabadeen Azam wa Akmal (2005) Urdu translation, CCRUM, New Delhi, 250-253.

9. Ali Ibn Abbas Majoosi (2010) Kamil-e-Sana`ah (Urdu translation by Ghulam Hasnain Kantoori), Idara kitabulshifa, New Delhi, II: Maqalah 9th, 2: 528-529.

10. Ibn Qafful Masihi (2000) Kitab ul Umdah fil Jarahat, CCRUM, New Delhi, I: 162.

11. Manoranjan Sahu, Ramesh Bhat, Kala Suhas Kulkarni (2003) Clinical evaluation of Himplasia in benign prostate hyperplasia. Medicine update 1(11): 75-78.

12. Mark HE, Mark G (2007) Benign Prostate Hyperplasia management in primary care screening and therapy. HSR\&D evidence synthesis pilot program-BPH. US Department of veteran affairs Health services research and Development services.

13. Surveillance Epidemiology Age Adjusted Cancer incidence in men in United States 1975-2005 "Surveillance Epidemiology and End Results" Program (SEER) Division of cancer control and population sciences. National Cancer Institute USA.

14. Osegbe DN (1997) Prostate cancer in Nigerians: facts and nonfacts. J Urol 157(4): 1340-1343.

15. Haas GP, Delongchamps N, Brawley OW, Wang CY, Dela RG (2008) World Wide Epidemiology of Prostate cancer: perspective from autopsy studies. Can J Urology 15(1): 3866-3871.

16. Mohammad Azam Khan (2006) Rumuz-i- Azam, CCRUM, New Delhi, II: 155-159.

17. Mohammad Azam Khan (1906) Iksir-i-Azam, Matab Nami, Munshi Naval Kishor Lucknow, IV: 289-308.

18. Muhammad Bin Zakariya Razi (1308) Kitab-al-Hawifil-Tibb, Daira Al-Maarif-Al-Usmaniya, Hyderabad, X: 153-188.

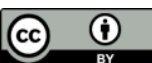

